\title{
DR. SIGMUND FREUD, ENSAIOS. MOISÉS E A RELIGIÃO MONOTEÍSTA, 1939 Miguel Angel P. Gaviria
}

\begin{abstract}
Resumo
Neste artigo pretende-se abordar o trabalho escrito por Sigmund Freud (1939) intitulado "Moises e a Religião Monoteísta", publicado na cidade de Amsterdam. Este livro é formado por três ensaios anteriores compreendidos entre os anos 1934 e 1938, estudos que formam parte da sua etapa final de pesquisa, correspondendo aos trabalhos de Psicanalise da cultura. Desloca-se o artigo com uma pequena introdução na historia, com a vida de Amenhotep IV (Akhenaton), Faraó da Dinastia XVIII compreendida entre os anos 1350 a 1333 a.C., promovedor e instaurador do Monoteísmo no antigo Egito, para arremeter logo à historia de Moises, segundo as analises de Freud e suas hipóteses sobre o nascimento de um herói e o nascimento de uma religião. Também se utiliza como referencia partes do texto de Paul Ricoeur (1990) em sua obra "Freud: Uma Interpretação Da Cultura", para complementar este artigo. Finalmente pretende-se deixar ao leitor uma conclusão aberta ficando sempre marcados os períodos de latência na historia entre a arte, religião e filosofia, em outras palavras, períodos marcados "mitologicamente" por Eros, Thanatos e Ananke; palavras que pode-se elucidar como; Amor, Morte e Necessidade.
\end{abstract}

Palavras chave: Freud, Psicanalise, Cultura, Monoteísmo, Herói.

\section{Abstract}

In this article we intend to approach the work written by Sigmund Freud (1939) entitled "Moses and monotheistic religion", published in the city of Amsterdam. This book consists of three previous tests between the years 1934 and 1938, studies which form part of the final stage of research, corresponding to the works of Psychoanalysis of the culture. Dislocated the article with a short introduction in the history, the life of Amenhotep IV (Akhenaten), Pharaoh of the EIGHTEENTH Dynasty between the years 1350 to $1333 \mathrm{BC}$, party promoter and establisher of monotheism in ancient Egypt, to swoop right from the story of Moses, according to the analysis of Freud and his assumptions about the birth of a hero and the birth of a religion. Also used as references parts of the text of Paul Ricoeur (1990) in his book "Freud: the interpretation of culture", to complement this article. Finally we intend to leave the reader to a conclusion open getting always marked the latency periods in the history of art, religion and philosophy, in other words, periods marked "mythologically" by Eros, Thanatos and Ananke; words that can elucidate how; Love, death and Need.

Key words: Freud, psychoanalysis, culture, monotheism, Hero. 


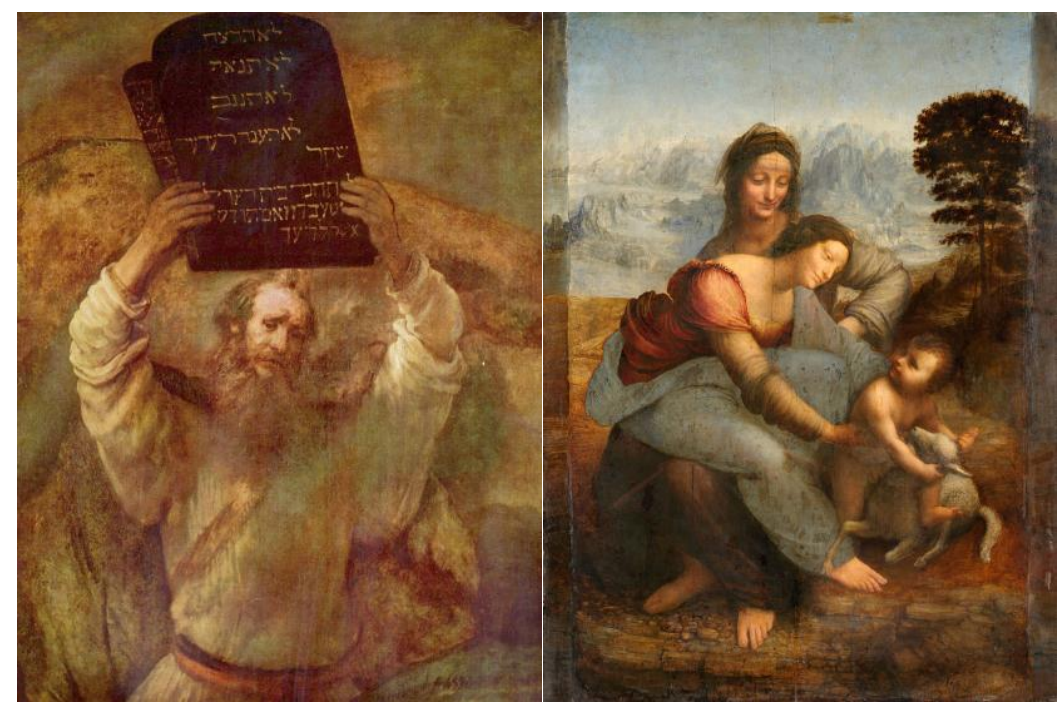

Imagem 1

Imagem 2

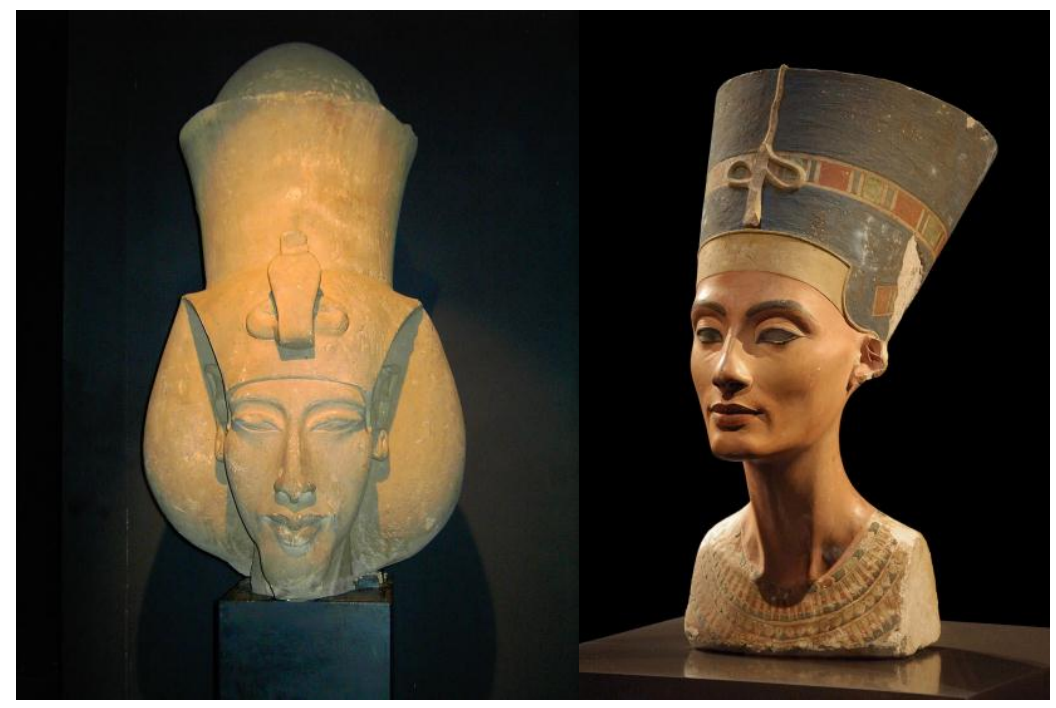

Imagem 3

Imagem 4

\section{ANTECEDENTE HISTÓRICO - AKHENATON (DINASTIA XVIII -}

\section{0-1333 A.C)}

É incerto se Amenhotep IV, filho mais novo de Amenhotep III e da rainha Tiy, chegou ao poder após a morte de seu pai, ou depois de um período indeterminado de regência. Em qualquer caso, no quarto ano do seu reinado o Egito caiu em um período de profundas mudanças e ideologias na religião e na arte sem precedentes. Abandonando os retratos tradicionais dos deuses, o governante fez-se representar, com sua esposa onipresente, Nefertiti, em atos de culto ao disco solar, identificado com o deus Aton, surgem raios que terminam em mãos. O homem de Deus e seus epítetos 
foram inseridos em cartuchos, como nomes reais, e um grande santuário dedicado ao deus sol em Karnak foi governado. Mesmo a iconografia do Faraó mudou radicalmente. Algumas estátuas colossais retratam o rei com um realismo extremo: o crânio alongado, rosto oval, lábios inchados, olhos amendoados, corpo andrógino e barriga flácida. $\mathrm{O}$ novo cânone iconográfico extensível aos membros da família real e alguns funcionários judiciais. E pela primeira vez na arte egípcia, o soberano é representado desempenhando atividades diárias, e há inúmeras cenas que retratam a família real em sua vida privada doméstica. Durante o quinto ano de seu reinado, Amenhotep IV começou sua nova capital, em uma área de deserto do Oriente Egito, perto da atual cidade de Amarna, onde se aposentou com sua corte para professar o culto de Aton. A fundação de uma nova cidade, Akhenaton ("Horizonte de Aton"), coincidiu com a mudança do nome verdadeiro: abandonou o nome que contém uma referência a Amun, o deus de Tebas, e adotou o nome Akhenaten. Adorar os deuses do panteão egípcio foram proibidos e fechou os santuários do país: o soberano impôs o culto exclusivo do disco solar e com apenas o casal real foi possível estabelecer uma relação direta. A composição poética, (Hino a Aton), foi provavelmente criado pelo próprio Ajenatón escrito sobre as paredes de um túmulo da cidade de Akhenaton. Para o décimo segundo ano de mandato, Akhenaton e Nefertiti viveram de forma estável na nova capital, onde tinham construído novos palácios e templos para o culto de Aton; Tiy (mãe de Akenhaton) viveu com eles, e a mãe real Nefertiti com suas seis filhas e outros membros da corte. Embora a política externa deste período é bem conhecida graças ao arquivo real de Amarna, não há nenhuma evidência de campanhas militares de destaque. Após o décimo segundo ano, parece que vários infortúnios talvez relacionadas a uma epidemia virulenta, marcou a última fase do reinado de Akhenaton; Tiy e duas de suas filhas morreram, e perdeu-se os monumentos de Kiya, esposa secundária. Akhenaton morreu no décimo sétimo ano de seu reinado, e foi sepultado no túmulo que havia aberto em Amarna. Seus fragmentos no sarcófago foram remontados e hoje se encontram no Museu Egípcio, no Cairo. O soberano deixou um Egito dividido abalado por profundas mudanças e um delicado problema de sucessão.

Parte do texto extraída no livro o arte dos Faraós (Traduçao Miguel Ángel P. Gaviria) 


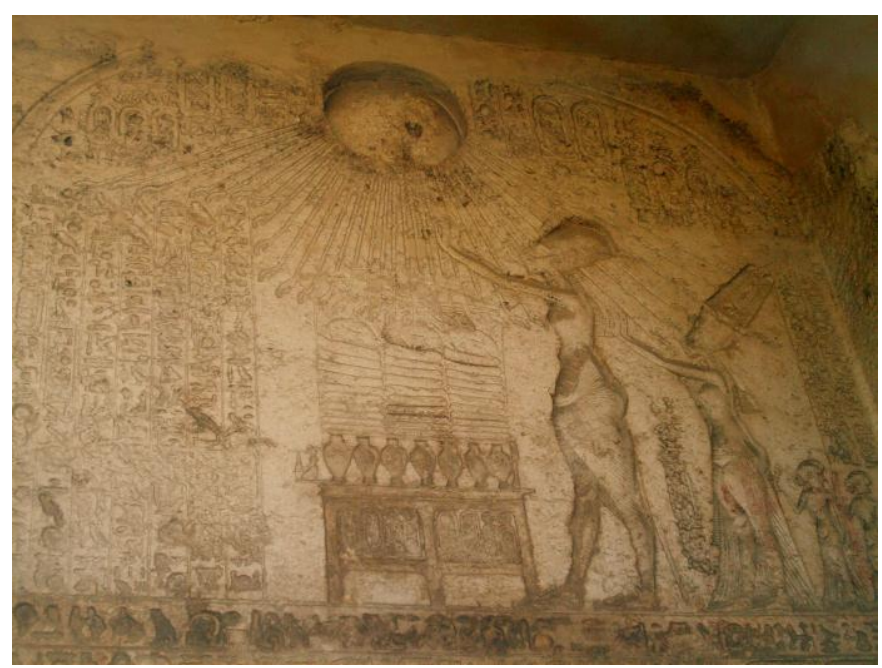

Imagem 5

Podemos comparar o Monoteísmo com o Totalitarismo definindo-o como um sistema de governo em que todos os poderes ficam concentrados nas mãos do governante. Desta forma, no regime totalitário não há espaço para a prática da democracia, nem mesmo a garantia aos direitos individuais. No regime totalitário, o líder decreta leis e toma decisões políticas e econômicas de acordo com suas vontades. Embora possa haver sistema judiciário e legislativo em países de sistema totalitário, eles acabam ficam às margens do poder. 


\section{Linhagem Pai e Filho - Akhenaten - Dinastia XVIII}

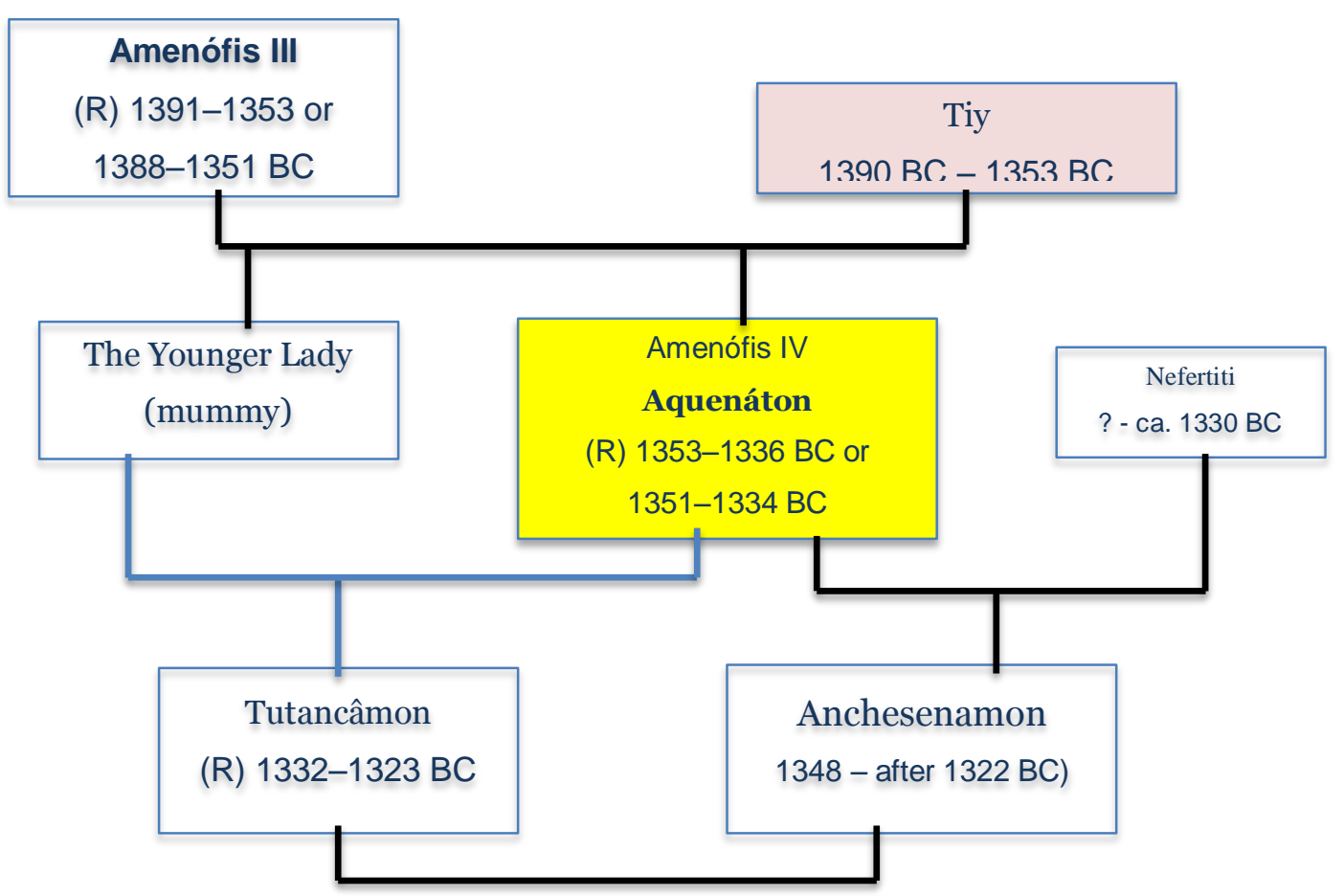

FONTE: Ian Shaw e outros (2002). The Oxford history of Ancient Egypt. Oxford University Press.

\section{MOISÉS E A RELIGIÃO MONOTEISTA}

Obra de Sigmund Freud publicado em Amsterdã, em alemão, no ano 1939 sob o título Der Mann Moses und die monotheistische Religião. Drei Abhandlungen. Livro escrito em seu exílio, publicado simultaneamente em Amsterdam e Londres. No mesmo ano da morte de seu autor, Moisés e o monoteísmo é uma das obras mais ousadas de Sigmund Freud, um dos mais falados e que, juntamente com o Totem e tabu, que é a continuação lógica, causou a maior controvérsia entre os especialistas. É uma obraprima, e o historiador Salo Baron Wittmayer não está errado em descrevê-lo, no momento de sua aparição, "magnífico castelo no ar", e apontam que "Quando um pensador da estatura de Freud toma posição sobre um assunto de interesse vital para ele, todos deveriam ouvir. " 
O ensaio de Freud começa com esta declaração:

Privar um povo do homem de quem se orgulha como o maior de seus filhos não é algo a ser alegre ou descuidadamente empreendido, e muito menos por alguém que, ele próprio, é um deles. Mas não podemos permitir que uma reflexão como esta nos induza a pôr de lado a verdade, em favor do que se supõe serem interesses nacionais; além disso, pode-se esperar que o esclarecimento de um conjunto de fatos nos traga um ganho em conhecimento. (Pág. 4)

No livro, Der Mythus von der Geburt des Helden (O mito do nascimento do herói) escrito por Otto Rank, discípulo e colaborador de Sigmund Freud, analisa os mitos de Sargon, Moisés, Karna, Édipo, Paris, Telephus, Perseu, Gilgamesh, Cyrus, Tristan, Romulus, Hercules, Jesus, Siegfried e Lohengrin. Em sua análise todas essas historias contêm características essenciais. Ele destaca símbolos recorrentes a todos esses mitos, tais como a água, a luta para nascer mesmo contra toda adversidade, e a vitória do herói. Otto Rank, quando ainda estava sob a influência de Freud publicou, seguindo a sugestão do seu professor, o livro 'Lenda Media'. Logo Freud apoiou-se neste livro para fundamentar certas hipóteses na historia do herói em seu ensaio Moisés e a Religião Monoteísta.

'O herói é filho de pais muito aristocráticos; geralmente, filho de um rei. 'Sua concepção é precedida por dificuldades, tal como a abstinência ou a esterilidade prolongada, ou seus pais têm de ter relações em segredo, por causa de proibições ou obstáculos externos. Durante a gravidez, ou mesmo antes, há uma profecia (sob a forma de sonho ou oráculo) que alerta contra seu nascimento, que geralmente ameaça perigo para o pai. 'Como resultado disso, a criança recém-nascida é condenada à morte ou ao abandono, geralmente por ordem do pai ou de alguém que o representa; via de regra é abandonada às águas, num cesto. 'Posteriormente ele é salvo por animais ou por gente humilde (tais como pastores) e amamentado por uma fêmea de animal ou por uma mulher humilde. 'Após ter crescido, redescobre seus pais aristocráticos depois de experiências altamente variadas, vinga-se do pai, por um lado, é reconhecido, por outro, e alcança grandeza e fama. (Pág. 6)

Freud comenta as seguintes representações simbólicas:

O abandono num cesto -----------------------nascimento 


Cesto-------------------------------------- útero
Água-------------------------------------- líquido amniótico
Relação genitor com a criança---------------tirar para fora ou salvar das águas
Família real ou aristocrática---------------- Família fictícia
Família humilde----------------------------- Família do "herói”

No 'romance familiar' ficção poética, o filho reage em sua relação emocional com seus genitores especialmente com o pai. O mito do nascimento do herói fica na imaginação do povo como um comportamento comum ao modelo de herói.

Eduard Meyer e outros especialistas presumiram que a lenda de Moises foi diferente. Otto Rank diz que por "motivos nacionalistas" a lenda modificou-se tal como a conhecemos no tempo atual, Freud comenta o seguinte: Em seu caso, a primeira família; em outros casos, a aristocrática, foi suficientemente modesta. Ele era filho de levitas judeus. Contudo, o lugar da segunda família, em outros casos a humilde, foi tomado pela casa real do Egito; a princesa o criou como se fosse seu próprio filho. Esse afastamento do tipo intrigou a muitas pessoas. $\mathrm{O}$ faraó, segundo eles, fora advertido por um sonho profético de que um filho nascido de sua filha traria perigo para ele e para seu reino. Dessa maneira, fez com que a criança fosse abandonada no Nilo, depois do nascimento, mas ela foi salva por judeus e criada como filho deles.

Basta a reflexão, uma lenda que não mais se desvie das outras, pois seria de os egípcios não tinham motivo para glorificar Moisés, visto este não ser um herói para eles. Temos de supor, então, que a lenda foi criada entre os judeus, o que equivale a dizer que foi ligada, em sua forma familiar [isto é, na forma típica de uma lenda de nascimento], à figura de seu líder. Mas ela era totalmente inapropriada para esse fim, pois que utilidade e poderia ter para um povo uma lenda que transformava seu grande homem em estrangeiro? (Pág. 8)

\section{Passo do totemismo ao monoteísmo}

O tema principal do ensaio de Moisés, "trata-se de uma ideia fundada na origem da religião monoteísta em geral". É preciso, pois, reconstruir com certa verossimilitude o acontecimento do assassinato que seja ao monoteísmo o que ou assassinato do pai primitivo haveria sido ao totemismo, representando frente a este 
último o papel de relevo, de reforço e amplificação, Freud no seu ensaio de Moisés aponta varias hipóteses um pouco arriscadas:

\section{MOISÉS EGÍPCIO SEGUIDOR DO CULTO DE ATEN}

...Surgiu a ideia de um deus universal Aten, a quem a restrição a um único país e a um único povo não mais se aplicava. No jovem Amenófis IV, chegou ao trono um faraó que não tinha interesse mais alto do que o desenvolvimento dessa ideia de um deus. Ele promoveu a religião de Aten a religião estatal e, através dele, o deus universal tornou-se o único deus: tudo o que se contava dos outros deuses era engano e mentira. $\mathrm{O}$ Moisés egípcio dera a uma parte do povo uma noção mais altamente espiritualizada de deus, não pode constituir fato sem importância que Akhenaten comumente se referisse a si mesmo, em suas inscrições, como “vivendo em Ma'at” (Verdade, Justiça).

Moisés, podemos perguntar: que significa seu nome?, qual é a sua origem? Segundo as deduções de investigadores como o mesmo Freud chega à conclusão que seu significado deriva do vocabulário egípcio Mós ou Més (Mose) que significa criança, deixando assim sua origem de nascimento no mesmo Egito. A circuncisão, prática utilizada pelo egípcios, também foi introduzida aos judeus por Moisés, podemos remeter-nos à uma lembrança do primevo com este termo da circuncisão, a castração dos filhos por parte do pai na horda primitiva .

\section{MONOTEISMO DE ATEN}

Se, contudo, colocarmos Moisés na época de Akhenaten e o supusermos em contato com esse faraó, o enigma se desfará, mostrando-se possíveis os motivos que responderão a todas as nossas perguntas. Comecemos pela suposição de que Moisés era um aristocrata, um homem proeminente, talvez, na verdade, um membro da casa real, tal como a lenda diz a seu respeito. Indubitavelmente, estava cônscio de suas grandes capacidades, era ambicioso e enérgico; pode ter inclusive acalentado a ideia de um dia 
vir a ser o líder de seu povo, de se tornar o governante do reino. Achando-se perto do faraó, era um aderente convicto da nova religião, cujos pensamentos básicos fizera seus.

\section{HERÓI MOISÉS}

O assassinato do líder Moisés, por parte de seu povo, Freud expõe nesta hipótese as conclusões de Ernst Sellin, teólogo, pioneiro na utilização da arqueologia no estúdio da bíblia, experto em línguas orientais onde expôs em seu livro, Mose und seine Bedeutung für die israelitisch-jüdische Religionsgeschichte (Moisés e sua importância para a história religiosa israelita-judaica), Leipzig, 1922, a teoria do assassinato a partir das escrituras dos profetas e suas alusões ao liberador dos judeus.

Moisés, derivando-se da escola de Akhenaten, não empregou métodos diferentes dos que o faraó usara; ele ordenou, forçou sua fé ao povo. A doutrina de Moisés pode ter sido inclusive mais dura do que a de seu mestre. (Pág. 25)

\section{PROFETAS JUDEUS ARTIFICES DO DEUS MOSAICO}

Surgiu então, dentre o povo, uma sucessão infindável de homens que não eram ligados a Moisés em sua origem, mas que foram cativados na obscuridade: foram esses homens, os profetas, que incansavelmente pregaram a antiga doutrina mosaica - a de que a divindade desdenhava o sacrifício e o cerimonial e pedia apenas fé e uma vida na Verdade e na Justiça (Ma'at). Os esforços dos profetas alcançaram sucesso duradouro; as doutrinas com que haviam restabelecido a velha fé tornaram-se o conteúdo permanente da religião judaica. É honra bastante para o povo judeu que tenha conseguido preservar tal tradição e produzir homens que lhe deram voz, ainda que a iniciativa para isso tenha provindo do exterior, de um grande forasteiro. (Pág. 28)

Podemos citar a Paul Recoeur nas suas conclusões nestas quatro hipóteses:

A primeira hipótese: Moisés egípcio, as presunções derivadas do nome de Moisés, como o relato de seu nascimento, a origem egípcia da circuncisão, não são de muito crédito nesta hipótese de um Moisés egípcio. Segunda hipótese: monoteísmo de 
Aten, que haveria sido elaborado conforme o modelo de um príncipe pacífico, o famoso faraó Akhenaten, e logo Moisés haveria imposto as tribos semitas. Ainda supondo que a religião de Aten e a personalidade fascinante de Akhenaten não sejam subestimadas, é duvidoso que tenha relação alguma com a religião hebraica. Terceira hipótese: o "herói" Moisés, no sentido de Otto Rank (cuja influencia es aqui considerável), haveria sido assassinado pelo povo e o culto ao deus de Moisés haveria se fundido com a de Javé, deus dos vulcões, disfarce sob o qual o deus de Moisés haveria dissimulado sua origem e também o assassinato do herói poderia assim cair no esquecimento. Desgraçadamente, a hipóteses de um assassinato de Moisés, sugerido por Sellin em 1922 com um contexto geográfico e histórico muito diferente, foi ulteriormente abandonada por o próprio autor. Também, tal hipótese força a desdobrar a Moisés, o Moisés do culto a Aten e o do culto a Javé, hipótese que não encontra apoio nenhum entre os especialistas. Quarta hipótese: os profetas judeus haveriam sido artífices do retorno ao deus mosaico; o mesmo acontecimento traumático haveria ressurgido sob os rasgos do deus ético, e o retorno ao deus mosaico seria, também, o retorno do traumatismo reprimido. Teríamos assim o ponto em que coincidem um ressurgimento no plano das representações e um retorno do reprimido no plano emocional. Se o povo judeu ofereceu à cultura ocidental seu modelo de autoacusação, isto se deveria a que seu sentido da culpabilidade se alimenta com a lembrança de um assassinato que trata ao mesmo tempo de dissimular.

\section{Aplicação - Trauma primitivo - Defesa - Latência}

O restabelecimento do pai primevo em seu direitos históricos constituiu um grande passo à frente, mas não podia ser o fim. As outras partes da tragédia préhistórica insistiam em ser reconhecidas. Não é fácil discernir o que colocou esse processo em movimento. Parece como se um crescente sentimento de culpa se tivesse apoderado do povo judeu, ou, talvez, de todo o mundo civilizado da época, como um precursor de retorno do material reprimido, até que, por fim, um desses judeus encontrou, ao justificar um agitador político- religioso, ocasião para desligar do judaísmo uma nova religião - a cristã. Paulo, um judeu romano de Tarso, apoderou-se 
desse sentimento de culpa e o fez remontar corretamente à sua fonte original. Chamou essa fonte de 'pecado original'; fora um crime contra Deus, e só podia ser expiado pela morte. (Pág. 48)

Se Moisés foi o primeiro Messias, Cristo tornou-se seu substituto e sucessor, e Paulo poderia exclamar para os povos, com certa justificação histórica: Olhai! O Messias realmente veio: ele foi assassinado perante vossos olhos!' Além disso, também, existe um fragmento de verdade histórica na ressurreição de Cristo, pois ele foi o Moisés ressurreto e, por trás deste, o pai primevo retornado da horda primitiva, transfigurado e, como o filho, colocado no lugar do pai. O pobre povo judeu, que, com sua obstinação habitual, continuava a repudiar o assassinato do pai, expiou-o pesadamente no decurso do tempo. Defrontou-se constantemente com a recriminação: 'Vocês mataram nosso Deus!' E essa censura é verdadeira, se for corretamente traduzida. Colocada em relação com a história das religiões, ela diz: "Vocês não admitem que mataram Deus (a figura primeva de Deus, o pai primevo, e suas reencarnações posteriores).' Deveria haver um acréscimo, declarando-se: 'Fizemos a mesma coisa, é verdade, mas o admitimos, e, desde então, fomos absolvidos.' (Pág. 50)

Freud compara a conformidade entre o indivíduo e o grupo, "o que é esquecido não se extingue, mas é apenas 'reprimido', seus traços mnêmicos estão presentes, mas isolados por anticatexias".

\section{A RENÚNCIA AO INSTINTO, ID-EGO-SUPEREGO}

Se o id de um ser humano dá origem a uma exigência instintual de natureza agressiva ou erótica, o mais simples e natural é que o ego, que tem o aparelho de pensamento e o aparelho muscular à sua disposição, satisfaça a exigência através de uma ação. Essa satisfação do instinto é sentida pelo ego como prazer, tal como sua não satisfação indubitavelmente se tornaria fonte de desprazer. Ora, pode surgir um caso em que o ego se abstenha de satisfazer o instinto, por causa de obstáculos externos, a saber, se percebesse que a ação em apreço provocaria um sério perigo ao ego. Uma abstenção da satisfação desse tipo, a renúncia a um instinto por causa de um obstáculo externo ou, como podemos dizer, em obediência ao princípio da realidade —, não é agradável 
em caso algum. A renúncia ao instinto conduziria a uma tensão duradoura, devida ao desprazer, se não fosse possível reduzir a intensidade do próprio instinto mediante deslocamentos de energia. A renúncia instintual, contudo, pode também ser imposta por outras razões, as quais corretamente descrevemos como internas. No curso do desenvolvimento de um indivíduo, uma parte das forças inibidoras do mundo externo é internalizada e constrói-se no ego uma instância que confronta o restante do ego num sentido observador, crítico e proibidor. Chamamos essa nova instância de superego. Doravante o ego, antes de colocar em funcionamento as satisfações instintuais exigidas pelo id, tem de levar em conta não simplesmente os perigos do mundo externo, mas também as objeções do superego, e terá ainda mais fundamentos para abster-se de satisfazer o instinto. Mas onde a renúncia instintual, quando se dá por razões externas, é apenas desprazerosa, quando ela se deve a razões internas, em obediência ao superego, ela tem um efeito econômico diferente. Em acréscimo às inevitáveis consequências desprazerosas, ela também traz ao ego um rendimento de prazer - uma satisfação substitutiva, por assim dizer. O ego se sente elevado; orgulha-se da renúncia instintual, como se ela constituísse uma realização de valor. Acreditamos que podemos entender o mecanismo desse rendimento de prazer. O superego é o sucessor e o representante dos pais (e educadores) do indivíduo, que lhe supervisionaram as ações no primeiro período de sua vida; ele continua as funções deles quase sem mudança. Mantém o ego num permanente estado de dependência e exerce pressão constante sobre ele. Tal como na infância, o ego fica apreensivo em pôr em risco o amor de seu senhor supremo; sente sua aprovação como libertação e satisfação, e suas censuras como tormentos de consciência. Quando o ego traz ao superego o sacrifício de uma renúncia instintual, ele espera ser recompensado recebendo mais amor deste último. A consciência de merecer esse amor é sentida por ele como orgulho. Na época em que a autoridade ainda não fora internalizada como superego, poderia ter havido a mesma relação entre a ameaça de perda do amor e as reivindicações do instinto; havia um sentimento de segurança e satisfação quando se conseguia uma renúncia instintual por amor ao país. Mas esse sentimento feliz só poderia assumir o peculiar caráter narcísico de orgulho depois que a própria autoridade se tivesse tornado parte do ego. (Pág. 65)

A religião que começou com a proibição de fabricar uma imagem de Deus transforma-se cada vez mais, no decurso dos séculos, numa religião de renúncias 
instintuais. Não é que ela exija abstinência sexual; contenta-se com uma acentuada restrição da liberdade sexual. Deus, contudo, afasta-se inteiramente da sexualidade e eleva-se para o ideal de perfeição ética. Mas a ética é uma limitação do instinto. Os profetas nunca se cansaram de asseverar que Deus nada exige de seu povo senão uma conduta de vida justa e virtuosa - isto é, abstenção de toda satisfação instintual, que ainda é condenada como impura também por nossa mortalidade atual. E mesmo a exigência de crença nele parece ficar em segundo lugar, em comparação com a seriedade desses requisitos éticos. Dessa maneira, a renúncia instintual parece desempenhar um papel preeminente na religião, mesmo que não se tivesse salientado nela desde o início. (Pág. 66)

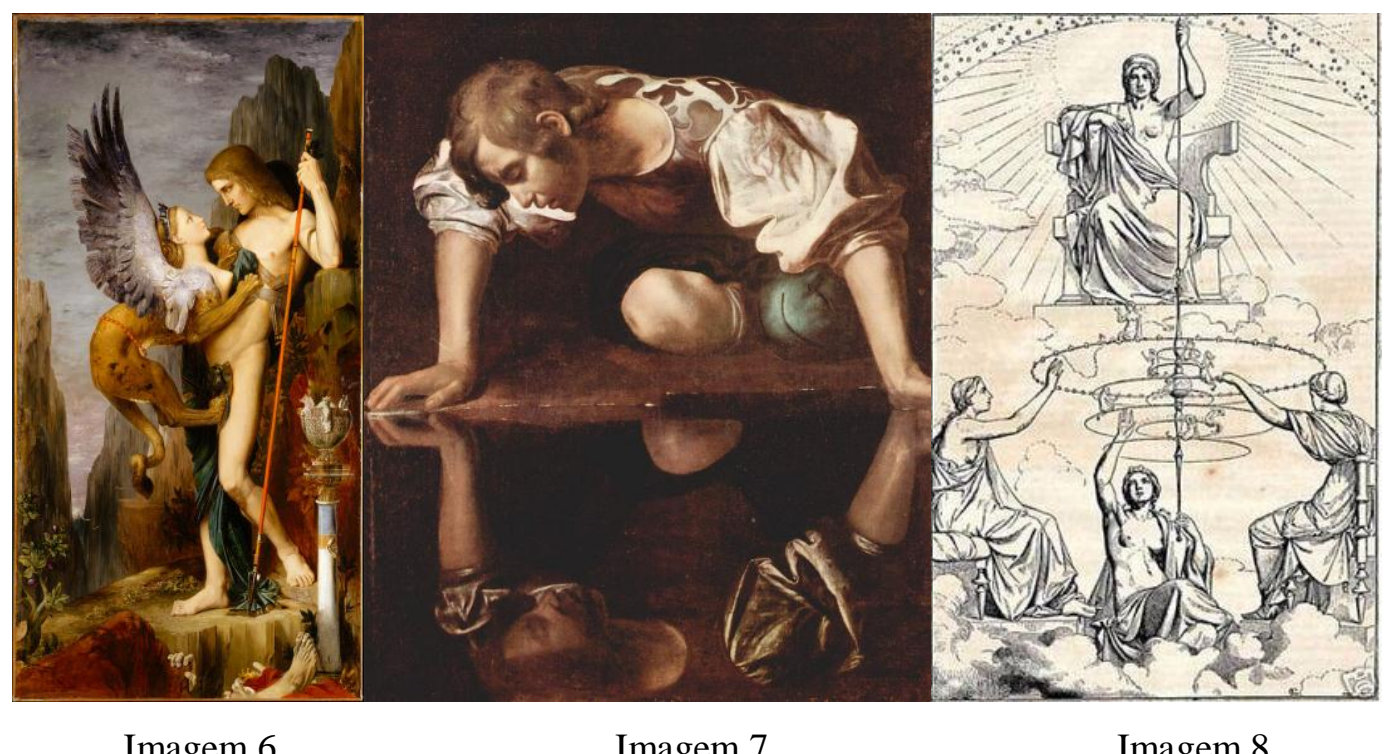

Retornando à ética, podemos dizer, em conclusão, que uma parte de seus preceitos se justifica racionalmente pela necessidade de delimitar os direitos da sociedade contra o indivíduo, os direitos do indivíduo contra a sociedade, e os dos indivíduos uns contra os outros. Mas o que nos parece tão grandioso a respeito da ética, tão misterioso e, de modo místico, tão auto-evidente, deve essas características à sua vinculação com a religião, à sua origem na vontade do pai. (Pág. 68) 


\section{O QUE É VERDADEIRO EM RELIGIÃo O RETORNO DO REPRIMIDO}

Descobrimos que o homem Moisés imprimiu nesse povo esse caráter dandolhes uma religião que aumentou tanto sua auto-estima que ele se julgou superior a todos os outros povos. (1) permitiu ao povo participar da grandiosidade de uma nova ideia de Deus, (2) afirmou que esse povo fora escolhido por esse grande Deus e destinado a receber provas de seu favor especial, e (3) impôs ao povo um avanço em intelectualidade que, bastante importante em si mesmo, lhe abriu o caminho, em acréscimo, à apreciação do trabalho intelectual e a novas renúncias aos instintos. (Pág. 68)

A fim de não perdermos a vinculação com nosso tema, devemos manter em mente o fato de que, no início de tal curso de acontecimentos, há sempre uma identificação com o pai na primeira infância. Esta é posteriormente repudiada e até mesmo supercompensada, mas, ao final, mais uma vez se estabelece. (Pág. 70)

\section{Verdade histórica o desenvolvimento histórico}

Tentemos abordar o assunto a partir da direção oposta. Compreendemos como um homem primitivo tem necessidade de um deus como criador do universo, como chefe de seu clã, como protetor pessoal. Esse deus assume posição por trás dos pais mortos [do clã], a respeito de quem a tradição ainda tem algo a dizer. Um homem de dias posteriores, de nossos próprios dias, comporta-se da mesma maneira. Também ele permanece infantil e tem necessidade de proteção, inclusive quando adulto; pensa que não pode passar sem o apoio de seu deus. (Pág. 71)

Saulo de Tarso (que, como cidadão romano, chamava-se Paulo), que a compreensão pela primeira vez emergiu: 'a razão por que somos tão infelizes é que matamos Deus, o pai,' E é inteiramente compreensível que ele só pudesse apreender esse fragmento de verdade no disfarce delirante da boa notícia: 'estamos libertos de toda culpa, uma vez que um de nós sacrificou a vida para absolver-nos.' Nessa fórmula, a morte de Deus naturalmente não foi mencionada, mas um crime que tinha de ser explicado pelo sacrifício de uma vítima só poderia ter sido um assassinato. E o passo intermediário entre o delírio e a verdade histórica foi proporcionado pela garantia de que derivou da fonte da verdade histórica, essa nova fé derrubou todos os obstáculos. $\mathrm{O}$ 
sentimento bem- aventurado de ser escolhido foi substituído pelo sentimento liberador da redenção. Mas o fato do parricídio, retornando à memória da humanidade, teve de superar resistências maiores do que o outro fato, que constituíra o tema geral do monoteísmo; ele também foi obrigado a submeter-se a uma deformação mais poderosa. O crime inominável foi substituído pela hipótese do que deve ser descrito como um indistinto 'pecado original'. (Pág. 75)

O pecado original e a redenção pelo sacrifício de uma vítima tornaram-se as pedras fundamentais de nova religião fundada por Paulo. Deve permanecer incerto se houve um cabeça e instigador ao crime entre o bando de irmãos que se rebelou contra o pai primevo, ou se tal figura foi criada posteriormente pela imaginação de artistas criativos, a fim de se transformarem em heróis, tendo sido então introduzida na tradição. Após a doutrina cristã ter queimado a estrutura do judaísmo, recolheu componentes de muitas outras fontes, renunciou a uma série de características do monoteísmo puro e adaptou-se, em muitos pormenores, aos rituais de outros povos mediterrâneos. Foi como se o Egito mais uma vez se vingasse dos herdeiros de Akhenaten.

Vale a pena notar como a nova religião lidou com a antiga ambivalência na relação com o pai. Seu conteúdo principal foi, é verdade, a reconciliação com o Deus pai, a expiação pelo crime cometido contra ele, mas o outro lado da relação emocional mostrava-se no fato de o filho, que tomara a expiação sobre si, tornar-se um deus, ele próprio, ao lado do pai, e, na realidade, em lugar deste. O cristianismo, tendo surgido de uma religião paterna, tornou-se uma religião filial. Não escapou ao destino de ter de livrar-se do pai. (Pág. 76)

\section{Conclusão do ensaio Moises...}

A alternância na obra de Freud entre a pesquisa médica e teoria da cultura testemunha a amplitude do projeto freudiano. Aliás, é na última parte da obra de Freud, onde são acumulados os grandes textos sobre a cultura. Moisés e o monoteísmo é apenas um fragmento de um importante trabalho de Freud que propôs aplicar o método psicanalítico para a Bíblia, é a teoria necessária para sua revisão de um assassinato real. A transição do totemismo ao monoteísmo, exigiu a renovação do crime, a fim de fortalecer e sublimar a figura do pai, aumentar a culpa, exaltar a reconciliação com o pai e mais tarde com o cristianismo, para ampliar a figura de substituição do filho. A morte 
de Cristo seria um outro endosso das origens da memória, enquanto a pascoa ressuscita Moises, a religião de Paulo, finalmente, iria completar este retorno do reprimido, o que leva à sua origem pré-histórica e dando o nome de pecado original: que ele tinha cometido um crime contra Deus e só a morte poderia repará-lo. Ao mesmo tempo coloca aqui sua antiga hipótese de rebelião filial: o culpado principal deveria ser o Redentor, chefe da horda fraternal, o mesmo herói rebelde da tragédia grega. "Com ele retorna o pai primevo da horda primitiva, certamente transfigurado e havendo tomado como filho, o lugar de seu pai." Apenas a repetição de uma morte real permitiu obter esse efeito de reforço, que Freud atribuiu totem à Deus. Mas a religião, aliás, não é pura ilusão, já que inclui "reminiscências históricas importantes." E, Moisés e a religião monoteísta, fala neste sentido de um "núcleo de verdade na religião." Por que essa insistência sobre a realidade das memórias? Para dar uma analogia com o fundamento real da religião e neurose obsessiva. De fato, se a analogia entre a ilusão e o sonho é baseado em caráter paternal, a analogia do complexo da criança entre religião e neurose deve ter a mesma base. Se é verdade que, "a criança humana não pode realizar o seu desenvolvimento cultural sem passar por uma fase mais ou menos definido de neurose." O futuro de uma ilusão, é a ideia de orientação de Moisés ao monoteísmo. A principal ocasião da correspondência entre o fenômeno da latência característica da neurose e "fenômeno latência" que Freud acredita ter descoberto na história do judaísmo, incluindo o assassinato de Moisés e do surgimento da religião Moisés, no tempo dos profetas. "Além disso, a espécie humana está sujeita a processos de conteúdo agressivo-sexual que deixam vestígios permanentes, mas foram descartados e esquecidos em sua maioria. Mais tarde, depois de um longo período de latência, esses processos são reativados, produzindo fenômenos comparáveis na sua estrutura e a sua tendência para sintomas neuróticos " A psicanálise faz analogia, fundada na religião; é, sem dúvida, o exemplo mais marcante da interação dentro da obra de Freud, a interpretação dos sonhos e neuroses, e hermenêutica da cultura. A interpretação dos sonhos, quando a análise descobre no sonho "nossos velhos desejos", "o desejo indestrutível". A repetição em todos os retornos, narcisismo sublime ou não, escritos que vão desde Totem e Tabu para Moisés e o Monoteísmo continua falando sobre repetição: a instância que impulsiona o homem a superar o desejo da criança é a mesma puxando-o de volta. 
A religião é, para Freud, na repetição monótona de suas próprias origens. É um eterno chutar no chão de sua própria história arcaica. A eucaristia cristã repete a refeição totem, como a morte de Cristo repete o profeta Moisés, que repete a morte do pai original. A epigenesis do problema da incredulidade do homem é solucionado apenas com a repetição, equivale constituir um sentimento religioso, uma rejeição de qualquer consideração sobre o que pode ser uma transformação do desejo e medo ao "retorno do reprimido". No primeiro estudo de Moisés e o Monoteísmo, se Moisés era egípcio, Deus teve que tomar uma religião ética constituída, assim como no culto de Aten, construído, sobre o modelo do faraó Akhenaten. Coloca em pleno vigor o enigma de um deus "político", quer dizer, um deus que define o pacto social e, portanto, levanta-se sobre o mérito do desejo e do medo para manter uma relação mais estreita com a reconciliação entre os irmãos com o assassinato do pai. Neste sentido, pode-se dizer que o desejo, em vez de medo, é o criador da religião. 


\section{REFERÊNCIAS BIBLIOGRAFICAS}

Freud, Sigmund; Moisés e o monoteísmo, esboço de psicanálise e outros trabalhos; Volume XXXIII (1937-1919)

Kothe, Flavio; Anotações das aulas de Teoria de Arte na Universidade de Brasília UnB; 2014.

- Ricoeur, Paúl; Freud, Una interpretación de la cultura; Siglo veintiuno de España editores, S.A. (octava edición en español 1990)

- Ian Shaw e outros The Oxfor history of Ancient Egypt. Oxford University Press. (2002).

- Giorgio Ferrero; El arte de los faraones; Editorial BLUME; 2011

\section{Livros de inteireos}

- Freud, Sigmund; Totem e Tabu.

- Yosef Hayim Yerushalmi, Freuds Moses - Endliches und unendliches Judentum, Wagenbach, Berlin 1993

- Moran, William L.; The Amarna Letters, Baltimore: Johns Hopkins University Press, 1992.

\section{Filmes}

- Freud, além da alma; John Huston; Estados Unidos; 1962.

- A Dangerous Method; David Cronenberg; Alemanha, Reino Unido, Canada; 2011.

- Time watch - Akhenaton And Nefertiti: The Royal Gods Of Egypt; BBC; 2002

- The Great Egyptians - The Rebel Pharaoh; Discovery Chanel; 1998

\section{Índice de imagens}

Imagem 1. Rembrandt; Moises, rompendo as tabuas da lei; Gemäldegalerie de Berlin; 1659

Imagem 2. Leonardo da Vinci; Virgin and Child with St. Anne (retouched). Museu Louvre; $1510-1513$.

Imagem 3. Amarna Estilo; Akhenaton; Musee national alexandrie

Imagem 4. Amarna Estilo; Nefertiti; Museum Berlin 
Imagem 5. Amarna Estilo; Faraó Aquenáton e sua família adorando a Aton Imagem 6. Gustave Moreau; Edipo; Metropolitan Museum of Art New York; 1864 Imagem 7. Michelangelo Caravaggio (atribuido); Narciso; Galleria Nazionale d'Arte Antica Roma Italia; 1595-1600

Imagem 8. Ananké e as Moiras; 